\title{
ЗАПАС ПЛАТОСПРОМОЖНОСТІ ЯК ГАРАНТІЯ РОЗВИТКУ РИНКУ СТРАХОВИХ ПОСЛУГ
}

\author{
Петрушенко Юрій Миколайович \\ доктор економічних наук, професор \\ Сумський державний університет (м.Суми, Україна) \\ ORCID: 0000-0001-9902-7577 \\ yuriy.petrushenko@gmail.com \\ Бойко Олена Іванівна \\ аспірант \\ Сумський державний університет (м.Суми, Україна) \\ elena.boyko82@gmail.com
}

\begin{abstract}
Страхування життя поступово стає невід'ємною частиною побуту громадян України. 3 метою підвищення якості обслуговування клієнтів, еффективності використання наявних та залучених ресурсів, виявлення проблемних точок та підвищення рівня конкурентоздатності страхових організацій необхідно проводити аналіз фінансових показників діяльності даних організацій. В статті розглянуті головні параметри, які є ключовими фракторами в системі гарантій роботи страхових компаній. Проводиться аналіз основних показників провідних компаній зі страхування життя який стосується платоспроможності, вирахувані коефріцієнти запасу платоспроможності та оцінено рівень стійкості даних компаній. Проведене дослідження показало, що запас платоспроможності є досить вагомим, хоча в процесі фінансової діяльності він має тенденції до змін, які є як незначними, так і досить значущими. Загалом, дані аналізу говорять про наявну достатність страхових резервів та відкритість даних компаній до введення нових законодавчих норм, що відповідають вимогам директиви Solvency II.
\end{abstract}

Ключові слова: платоспроможність, фактичний запас платоспроможності, нормативний запас платоспроможноcmi, Solvency I, Solvency II

DOI: https://doi.org/10.32845/bsnau.2019.1.2

Постановка проблеми. У розвинених країнах світу страхування життя $є$ важливою складовою у формуванні власних заощаджень, інструментом фінансового захисту в разі настання непередбачуваних подій. В Україні компанії зі страхування життя, які є учасниками системи недержавного пенсійного забезпечення та мають право займатися даним видом діяльності працюють у відповідності до законів України, які регулюють цей вид діяльності. В процесі розвитку європейського страхового ринку практика показує, що зі змінами в економічних процесах, системи нагляду і контролю також необхідно доопрацьовувати та змінювати. На сьогоднішній день український страховий ринок теж має такі проблеми.

Відповідно, актуальним завданням $є$ досконале вивчення причин та наслідків даних змін та впровадження нових дієвих важелів, які б дали змогу державним органам більш ефективно впливати на розвиток вітчизняного страхового ринку з одного боку, та страховим компаніям надавати ширший спектр послуг та мати надійніші умови роботи з іншого боку. На сьогоднішній день дані завдання в країнах $€_{\text {в- }}$ ропейського Союзу регулюються та контролюються двома директивами - «Solvency l» та «Solvency Il». В Україні діяльність страхових організацій що займаються страхуванням життя контролюється Законом України «Про страхування» від 7 березня 1996 року N 85/96-ВР та Законом України «Про загальнообов'язкове державне пенсійне страхування» від 9 липня 2003 року № 1058-IV. Одним із основних показників, які забезпечують страхові організації позитивним результатом роботи $є$ платоспроможність. Платоспроможність засвідчує можливості страховика виконати страхові зобов'язання згідно з умовами договору страхування. Саме наявність відповідної суми для здійснення страхової виплати у визначений час і характеризує рівень платоспроможності страховика. Проте на

сьогоднішній день система оцінки платоспроможності страхових компаній є спрощеною формою європейської системи оцінки платоспроможності Solvency I. Це означає, що державні органи регулювання не мають вагомих та необхідних механізмів контролю. Тобто система оцінки платоспроможності страховиків не дозволяє отримувати об'єктивні дані. Для того, щоб вирішити проблему планується перейти до системи оцінки платоспроможності, яка має назву Solvency II. Цілі і завдання Директиви ЄC Solvency II: встановлення єдиної системи нормативно-правового регулювання в рамках $Є С$ для забезпечення страхувальників шляхом створення одноосібних стандартів управління ризиками і забезпеченням достатньої капіталізації.

Так як Україна підписала угоду про «Асоціацію з ЄС», то і законодавча база повинна відповідати нормам законодавства ЄС. Проблема оцінки платоспроможності страховиків була і залишається актуальною в умовах як сучасного українського страхового ринку, так і європейського. Важливим елементом досліджень $€$ аналіз фактичного запасу платоспроможності компаній зі страхування життя. За результатами даного дослідження можна зробити прогнози щодо спроможності компаній еффективно функціонувати на ринку послуг в умовах введення нових норм та правил. Актуальність дослідження обумовлена також тим, що існування повноцінного ринку страхування є важливою умовою для підвищення добробуту населення та сталого економічного зростання.

Аналіз останніх досліджень та публікацій. Серед основних показників стійкості та успішної роботи страхових компаній $є$ запас платоспроможності, який регулюється положеннями директив Solvency I та Solvency II. Вчені, які вивчають теоретичні та практичні аспекти даного показника погоджуються, що регулювання норм українського законодавства 
у відповідності до європейських стандартів щодо платоспроможності страхових організацій призведе до стабілізації ринку страхування життя в Україні. Так, В.Юхименко, аналізуючи положення Директиви Solvency II, акцентує увагу на тому, що розвиток системи платоспроможності страхових компаній в країнах $€ С$ показує логічність та систематичність підходу та є динамічною і постійно змінюваною величиною. Це в свою чергу $є$ передумовою значного впливу на страховий ринок та призведе до зміни методів та стандартів здійснення нагляду за його роботою. В результаті це стане причиною підвищення привабливості страхування життя для потенційних клієнтів [1, 169-172]. Метою впровадження нової Директиви $є$ підвищення рівня конкурентоспроможності страхових компаній і, відповідно, покращення фінансової безпеки. Це матиме позитивний вплив на діяльність страхових компаній, що працюють в країнах Європейського союзу, так як завдяки єдиним стандартам їх діяльність буде оптимізована [2]. Стосовно українського страхового ринку, то застосування вимог Solvency II призведе до зменшення кількості як компаній зі страхування життя, так і ризикових компаній та відбудеться концентрація страхового капіталу [3, 190-193]. Н.Богомаз, вивчаючи проблеми та перспективи розвитку єдиного страхового ринку країн Європейського Союзу, акцентує увагу та окреслює переваги введення системи контролю платоспроможності II, що в свою чергу може бути значущим фактором при впровадженні даної системи в діяльність страхових компаній на території України [4, 13-18].

Н.М.Внукова розглядає особливості адаптації вимог Solvency II в системі оцінки платоспроможності в контексті українського законодавства та пропонує практичні поради щодо розрахунку необхідного порогу платоспроможності [5, 76-82].

Н.Шлапак наголошує не лише на необхідності переходу на міжнародні стандарти обліку та звітності, а й на підвищенні значимості пенсійного та інвестиційного страхування. А перехід до рискорієнтованої системи Solvency II дасть змогу контролювати внутрішні системи страхових компаній, достатність рівня капіталу страховика [6].

О.В.Баранова говорить про необхідність введення системи Solvency II, що дозволить зацікавити інвесторів на роботу на ринку України, а страхові компанії зможуть надавати якісніші послуги, що збільшить клієнтський портфель кожного страховика [7].

Мета статті. Метою статті є дослідження рівня платоспроможності компаній зі страхування життя та виявлення готовності даних організацій до запровадження норм Solvency II.

Виклад основного матеріалу. Досліджуючи роботу компаній зі страхування життя можна спостерігати багато протиріч та невиконань своїх зобов'язань як перед страхувальниками так і перед акціонерами компаній. Серед головних причин, які призводять до даних проблем $є$ неналежне управління та рішення щодо ризиків, які не відповідають вимогам законодавства. Наслідком некоректних управлінських рішень виникає питання щодо платоспроможності страхових компаній, яка вважається ключовим показником в системі гарантій їх діяльності. Платоспроможність - це здатність страхової компанії планувати надходження грошових коштів та проведення вчасно грошових розрахунків по зобов'язанням, які поділяються на 2 групи:

1. зовнішні зобов'язання, що означає зобов'язання перед страхувальниками, фінансовими установами, перестрахувальниками, бюджетом;

2. внутрішні зобов'язання, що означає зобов'язання перед засновниками, представництвами та філіями, співробітниками.

Запас платоспроможності утворюють власні кошти страховика, які складаються із залучених коштів, страхових резервів, власних коштів (статутний капітал, спеціальні та резервні фонди, вільні резерви, нерозподілений прибуток).

В статті 30 Закону України «Про страхування» встановлені умови забезпечення платоспроможності страховиків [8]. Відповідно до цих положень необхідно дотримуватись наступних умов: наявності сплаченого статутного фонду, наявності гарантійного фонду страховика, створення страхових резервів, достатніх для майбутніх виплат страхових сум та страхових відшкодувань; перевищення фактичного запасу страховика над розрахунковим нормативним запасом платоспроможності. Платоспроможність контролюється державами у більшості країн світу шляхом перевірки дотримання страховими організаціями норм діяльності. В країнах Євросоюзу вона регулюються спеціальними директивами Solvency I та Solvency II.

В Україні діє система оцінки платоспроможності страховиків, яка називається Solvency I, яка була прийнята в роботу в 2002

Solvency I - перша директива для компаній зі страхування життя, яка була прийнята в 1979 році. Це був перший крок до гармонізації нагляду над діяльністю страхових компаній в Європі. Наглядовий режим Solvency I удосконалювався другою та третьою директивами (Директиви 88/357/€С, 90/619/ЄС, 92/49/ЄС та 92/96/ЄC). Вони запровадили свободу надання послуг в страховому секторі.

Робота щодо вдосконалення та пошуку нових шляхів розвитку вже існуючих правил Solvency I в країнах ЄC розпочалася на європейському рівні у 1990-х роках. Європейські правила платоспроможності пройшли порівняльну експертизу робочою групою на чолі з колишнім президентом Федерального управління страхового нагляду (Bundesaufsichtsamt für das Versicherungswesen - BAV), доктором Хельмутом Мюллером. У своєму заключному звіті, який має назву Доповідь Мюллера, робоча група зазначила, що європейські правила платоспроможності по суті витримали випробування часом. Проте результат розгляду також показав, що існуючі положення про власні кошти не відповідають адекватно всім ризикам, яким піддається страховик. Тому було прийнято рішення про комплексну реформу положень про власні кошти. Спочатку були впроваджені лише найнеобхідніші зміни до Solvency I Директивою про страхування життя (Директива 2002/83 ( ЄС) та Директивою щодо вимог щодо маржі платоспроможності для ризикових страхових компаній (Директива 2002/13 / ЄС). Положення Директив першого-третього покоління щодо убезпечення життя, які продовжували застосовуватися, були включені до Директиви про страхування життя. Ці Директиви були перенесені в національне законодавство через німецький закон, що здійснює регуляторні положення про реорганізацію та ліквідацію страхових компаній та кредитних установ. Проте обидві Директиви представляли лише перехідне рішення щодо нової системи нагляду на основі ризиків. Фундаментальна реформа правил платоспроможності для страховиків залишалася прерогативою наглядового режиму Solvency II [9].

Вісник Сумського національного аграрного університету

Серія «Економіка і менеджмент», випуск 1 (79), 2019 
Директиви третього покоління про страхування життя (92/96 / ЄС) та ризикове страхування (92/49 / ЄС) встановили єдиний ринок страхування в середині 1990-х років. Це дало $€ С$ створити один з найбільш конкурентоспроможних страхових ринків у світі. Страхові підприємства, на підставі дозволу в будь-якій державі-члені, мають право продавати в межах $€ C$ без будь-якого цінового контролю або попереднього повідомлення про умови (крім обов'язкового страхування). Ця система спирається на взаємне визнання нагляду, що здійснюється різними національними органами влади відповідно до правил, гармонізованих у міру необхідності на рівні ЄС. Вимога страхових компаній до встановлення адекватної межі платоспроможності $€$ одним з найважливіших загальних пруденційних правил [10].

У вітчизняній практиці практично впроваджено положення Solvency I. Необхідно зазначити, що при застосуванні положень Solvency I специфіка профілю певних ризиків конкретної страхової компанії не береться до уваги. Тому, на сучасному етапі розглядається механізм впровадження у вітчизняну практику положень Solvency II [11].

В 2018 р. було прийнято розпорядження № 850 «Про затвердження Положення про обов'язкові критерії і нормативи достатності капіталу та платоспроможності, ліквідності, прибутковості, якості активів та ризиковості операцій страховика». Дане положення набуло чинності 3 серпня 2018p. Відповідно до правил даного положення розмір статутного капіталу для компаній зі страхування життя складе 45 млн грн. Дані норми будуть діяти з 30 червня 2020 року. Проте до кінця 2018-го року компанії мали сформувати мінімальний статутний капітал в розмірі 30\% від необхідної суми, тобто 13,5 млн. грн., а до 30 червня 2019 року - вже 60\%, тобто 27 млн. грн. [12].

Ми можемо розглянути наскільки виконані дані умови компаніями зі страхування життя, які є лідерами вітчизняного страхового ринку, розрахувавши показники в відсотках. Для аналізу платоспроможності компаній зі страхування життя ми використали фінансові показники тих компаній, які мають 100\%-й іноземний статутний капітал (ПрАТ «Метлайфф» [16], ПрАТ «СК УНІКА Життя» [17], ПрАТ «СК «КД Життя» [18]), які мають частковий іноземний капітал (ПрАТ «УСК «Княжа Вієнна Іншуранс Груп» [19]) та які мають 100\%-й український капітал (ПрАТ «УАСК АСКА-ЖИТТЯ» [20], ПрАТ «СК «ТАС» [21]).

В Таблиці 1 наведено розмір статутного капіталу на кінець 2018 року та розмір у відсотках відповідно до вимог. Стовпчик 3 показує відсоткове співвідношення наявного статутного капіталу до мінімально необхідного розміру, який дорівнює 45 млн.грн. Ми можемо побачити, що на сьогоднішній день лише 3 компанії мають навіть перевищений розмір необхідного статутного капіталу. Стовпчик 4 показує відсоткове співвідношення наявного статутного капіталу до мінімально необхідного розміру, який дорівнює $30 \%$ від необхідного. На кінець звітного 2018 року ми спостерігаємо, що всі лідируючі компанії мають розмір статутного капіталу, що відповідає нормам законодавства, які були встановлені на кінець 2018 року.

Таблиця 1

Статутний капітал, тис.грн. та його відсоткове співвідношення до мінімальних необхідних розмірів

\begin{tabular}{|l|c|c|c|}
\hline \multicolumn{1}{|c|}{ Компанія } & 2 & 3 & 4 \\
\hline \multicolumn{1}{|c|}{} & Статутний капітал, тис.грн & $\%$ & $\%$ \\
\hline Уніка Життя & 100090,00 & 222,42 & 741,41 \\
\hline Метлайф & 102925,00 & 228,72 & 762,41 \\
\hline TAC & 93322,00 & 207,38 & 691,27 \\
\hline Граве Україна Страхування Життя & 26903,00 & 199,28 \\
\hline PZU Україна Страхування Життя & 32540,00 & 79,78 & 241,04 \\
\hline АСКА-Життя & 19385,00 & 43,08 & 143,59 \\
\hline Княжа Лайф Вієнна Інсшуаренс Груп & 33551,00 & 74,56 & 248,53 \\
\hline КД-Життя & 36015,00 & 80,03 & 266,78 \\
\hline Інго Україна Життя & 21000,00 & 46,67 & 155,56 \\
\hline
\end{tabular}

Складено та розраховано за даними [13].

Додатково регулятор посилив вимоги до активів, які можуть враховуватися під час розрахунку нормативів платоспроможності. Не менше 20-40\% страхових резервів (в залежності від виду діяльності) мають бути низькоризиковими. Так, якщо кредитний рейтинг банку, де розміщені активи страхової компанії, знижуватиметься, страховикам доведеться враховувати лише частину вартості таких активів: відразу після зниження рейтингу - в розмірі 75\%, через 30 днів після зниження рейтингу - не більше 50\%, через 60 днів - до $25 \%$, а через 90 днів такі активи взагалі не можна включати до суми прийнятних активів. Крім того, Нацкомфінпослуг заборонила враховувати активи, розміщені в неплатоспроможних банках [12].

Головною метою введення системи Solvency $\|$ є підвищення захищеності власників полісів. Платоспроможність як одна зі складових розраховується на основі стандартної формули, яка включає базовий необхідний платоспроможний капітал, об'єм капіталу, необхідний для операційного ризику та результат коригування здатності технічних резервів та відкладених податків покривати витрати [14]. Впровадження системи платоспроможності Solvency II ґрунтується на понятті «ризик». Це означає, що на кожен ризик, який приймається на страхування має бути відповідний розмір наявного капіталу. Ступені ризику використовуються для визначення розміру економічного капіталу, який необхідно зберігати в резерві з метою захисту компанії від будь-яких негативних ризикових впливів, які можуть виникнути в майбутньому.

Оскільки діяльність компаній зі страхування життя тісно пов'язана з пенсійним забезпеченням, то це є довгостроковими фінансовими зобов'язаннями і відповідно, такі вклади повинні бути захищені впродовж довгого періоду часу.

Нині в Україні гарантією платоспроможності страховиків $€$ адекватні зобов'язанням страхові резерви і власний капітал.

В Таблиці 2 наведено зміни в розмірі страхових резервів протягом 2010-2018 рр. Збільшення розміру страхових резервів пояснюється збільшенням надходжень страхових премій. Компанія ПрАТ «УАСК АСКА-ЖИТТЯ» показує зменшення 
розміру страхових резервів, причиною чого є здійснення значної кількості виплат по довгостроковим зобов'язанням протягом 2016-2018 pp.
На рис. 1 наведено динаміку зміни величини власного капіталу лідируючих компаній зі страхування життя в період $2011-2018$ рр. в тис.грн.

Таблиця 2

\begin{tabular}{|c|c|c|c|c|c|c|c|c|c|c|}
\hline \multicolumn{11}{|c|}{ Страхові резерви, тис.грн. } \\
\hline № & Страхові компанії & 2018 & 2017 & 2016 & 2015 & 2014 & 2013 & 2012 & 2011 & 2010 \\
\hline 1 & $\begin{array}{c}\text { Граве Україна } \\
\text { Страхування Життя } \\
\end{array}$ & 2560564,00 & 2425915,00 & 2240218,00 & 1968645,00 & 1349694,90 & 736669,70 & 648873,70 & 565052,30 & 502883,00 \\
\hline 2 & TAC & 2246104,00 & 2066736,00 & 1451795,00 & 1241797,00 & 909259,00 & 614547,00 & 527215,00 & 418248,00 & 312695,00 \\
\hline 3 & Метлайф & 2164819,00 & 1759322,00 & 1473461,00 & 1202853,00 & 1004531,00 & 1008149,00 & 809842,00 & 647233,00 & 502883,00 \\
\hline 4 & Уніка Життя & 715065,00 & 620765,00 & 458781,00 & 459230,00 & 229096,00 & 134350,00 & 106921,00 & 70104,00 & 54633,00 \\
\hline 5 & $\begin{array}{c}\text { PZU Україна Страхування } \\
\text { Життя } \\
\end{array}$ & 636016,00 & 539474,00 & 503067,00 & 456029,00 & 429685,00 & 241981,00 & 182203,00 & 131706,10 & 91510,80 \\
\hline 6 & $\begin{array}{c}\text { Княжа Лайф Віннна } \\
\text { Інсшуаренс Груп } \\
\end{array}$ & 360387,00 & 320419,00 & 270760,00 & 223496,00 & 147791,00 & 79765,00 & 59209,00 & 43399,00 & 28672,00 \\
\hline 7 & КД-Життя & 186388,00 & 164293,00 & 135552,00 & 105495,00 & 82806,00 & 61872,00 & 48915,00 & 37170,00 & 26608,00 \\
\hline 8 & АСКА-Життя & 87314,00 & 110375,00 & 141653,00 & 159932,00 & 162979,00 & 161967,00 & 154176,00 & 147997,00 & 147200,00 \\
\hline 9 & Iнго Україна Життя & 18765,00 & 14871,80 & 12235,80 & 7637,90 & 5248,90 & 3772,60 & 3036,90 & 3275,00 & 3404,00 \\
\hline
\end{tabular}

Складено за даними [13].

Pис.1

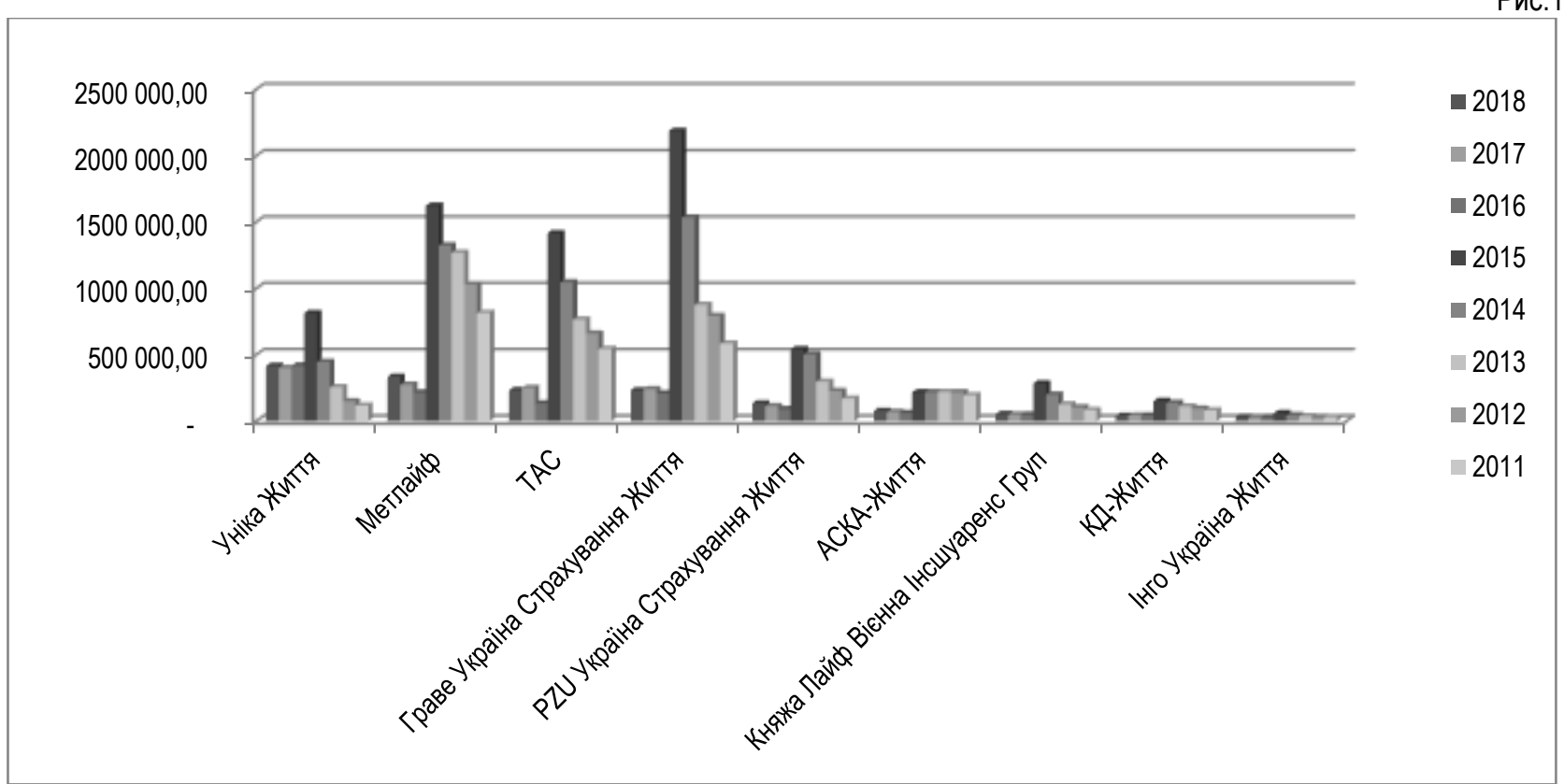

Складено за даними [13].

Можна сказати, що в кризові роки всі компанії зі страхування життя значно збільшили розмір власного капіталу.

Для того, щоб оцінити запас платоспроможності важливо брати до уваги коефіцієнт запасу платоспроможності. Він показує в скільки разів фрактичний запас платоспроможності більший за нормативний [15, 114-119]. 3 цією метою необхідно визначити фактичний запас платоспроможності (ФЗП) та нормативний (НЗП). ФЗП визначається за формулою: $Ф 3 П$ = загальна сума активів - нематеріальні активи сума загальних зобов'язань. НЗП = резерв довгострокових зобов'язань ${ }^{*} 0,05$. Коефріцієнт запасу платоспроможності показує у скільки разів фактичний запас платоспроможності перевищує нормативний запас платоспроможності, що свідчить про ефективне використання ресурсів, які знаходяться в розпорядженні страхових компаній. КЗП = ФЗП/НЗП.

В Таблиці 3 продемонстровано розрахунки, відповідно до яких підсумовані коефіцієнти запасу платоспроможності лідируючих компаній зі страхування життя.
Досить високі показники запасу платоспроможності показують ПрАТ «СК УНІКА Життя» та ПрАТ «УАСК АСКАЖИТТЯ». ПрАТ «СК «КД Життя» мали високі показники в період 2010-2014 рр. ПрАТ «СК «ТАС» мала від'ємний показник платоспроможності в 2016 р. Це пояснюється витратами на купівлю акцій ПрАТ «СК «ЕЙГОН ЛАЙФ УКРӒ̈НА». Компанії ПрАТ «Метлайф» та ПрАТ «УСК «Княжа Вієнна Іншуранс Груп» в порівнянні з іншими мають достатні показники.

Поряд з такими досить вагомими показниками по провідним компаніям виникає питання щодо компаній, які мають лише мінімальний запас платоспроможності. Введення досить жорстких вимог може призвести до зменшення кількості компаній, які займаються страхуванням життя. Це може мати негативний вплив на довіру до ринку страхування, так як пересічні громадяни знову матимуть недостовірну інформацію про причини таких змін. 
Таблиця 3

\begin{tabular}{|c|c|c|c|c|c|c|c|c|c|}
\hline Компанія & Рік & $\begin{array}{c}\text { Загальна сума } \\
\text { активів, тис.грн }\end{array}$ & $\begin{array}{c}\text { Загальна сума } \\
\text { нематеріальних } \\
\text { активів, тис.грн }\end{array}$ & $\begin{array}{c}\text { Загальна сума } \\
\text { зобов'язань, } \\
\text { тис.грн. } \\
\end{array}$ & $\begin{array}{c}\text { Фактичний запас } \\
\text { платоспроможності }\end{array}$ & $\begin{array}{c}\text { Резерв } \\
\text { довгострокових } \\
\text { зобов'язань }\end{array}$ & $\begin{array}{l}\text { Нормативний запас } \\
\text { платоспроможності }\end{array}$ & $\begin{array}{c}\text { Оцінка } \\
\text { платоспроможності } \\
\text { страхової компанії }\end{array}$ & $\begin{array}{c}\text { Коефіціент } \\
\text { запаса } \\
\text { платоспромо } \\
\text { жності }\end{array}$ \\
\hline \multirow[t]{9}{*}{ Metlife } & 2018 & 2631122,00 & 1192,00 & 2297717,00 & 332213,00 & 2164819,00 & 108240,95 & 223972,05 & 3,07 \\
\hline & 2017 & 2132742,00 & 2887,00 & 1858432,00 & 271423,00 & 1759322,00 & 87966,10 & 183456,90 & 3,09 \\
\hline & 2016 & 1851866,00 & 4734,00 & 1637415,00 & 209717,00 & 1473461,00 & 73673,05 & 136043,95 & 2,85 \\
\hline & 2015 & 1623242,00 & 533,00 & 1271008,00 & 351701,00 & 1202853,00 & 60142,65 & 291558,35 & 5,85 \\
\hline & 2014 & 1323340,00 & 581,00 & 1068448,00 & 254311,00 & 1006054,00 & 50302,70 & 204008,30 & 5,06 \\
\hline & 2013 & 1268659,00 & 673,00 & 1084552,00 & 183434,00 & 1011378,00 & 50568,90 & 132865,10 & 3,63 \\
\hline & 2012 & 1030418,00 & 1235,00 & 849998,00 & 179185,00 & 812626,00 & 40631,30 & 138553,70 & 4,41 \\
\hline & 2011 & 818262,00 & 1570,00 & 683575,00 & 133117,00 & 659243,00 & 32962,15 & 100154,85 & 4,04 \\
\hline & 2010 & 643652,00 & 517,00 & 535605,00 & 107530,00 & 511218,00 & 25560,90 & 81969,10 & 4,21 \\
\hline \multirow[t]{7}{*}{ Уніка } & 2018 & 1189332,00 & 208,00 & 773548,00 & 415576,00 & 715065,00 & 35753,25 & 379822,75 & 11,62 \\
\hline & 2017 & 1075473,00 & 402,00 & 675134,00 & 399937,00 & 622152,00 & 31107,60 & 368829,40 & 12,86 \\
\hline & 2016 & 891777,00 & 2651,00 & 474493,00 & 414633,00 & 458781,00 & 22939,05 & 391693,95 & 18,08 \\
\hline & 2015 & 812744,00 & 2512,00 & 478591,00 & 331641,00 & 459230,00 & 22961,50 & 308679,50 & 14,44 \\
\hline & 2014 & 445762,00 & 2725,00 & 249378,00 & 193659,00 & 229096,00 & 11454,80 & 182204,20 & 16,91 \\
\hline & 2013 & 255602,00 & 2333,00 & 150688,00 & 102581,00 & 134350,00 & $\begin{array}{l}6717,50 \\
\end{array}$ & 95863,50 & 15,27 \\
\hline & 2012 & 149079,00 & 2059,00 & 114291,00 & 32729,00 & 106921,00 & 5346,05 & 27382,95 & 6,12 \\
\hline \multirow[t]{6}{*}{ Княжа } & 2018 & 422896,00 & 155,00 & 369815,00 & 52926,00 & 360387,00 & 18019,35 & 34906,65 & 2,94 \\
\hline & 2017 & 381110,00 & 135,00 & 332813,00 & 48162,00 & 320419,00 & 16020,95 & 32141,05 & 3,01 \\
\hline & 2016 & 327235,00 & 119,00 & 279153,00 & 47963,00 & 270760,00 & 13538,00 & 34425,00 & 3,54 \\
\hline & 2015 & 283081,00 & 228,00 & 236476,00 & 46377,00 & 223496,00 & 11174,80 & 35202,20 & 4,15 \\
\hline & 2014 & 198914,00 & 142,00 & 154250,00 & 44522,00 & 147791,00 & 7389,55 & 37132,45 & 6,02 \\
\hline & 2013 & 126709,00 & 121,00 & 84766,00 & 41822,00 & 79777,00 & 3988,85 & 37833,15 & 10,48 \\
\hline \multirow[t]{4}{*}{ ACKA } & 2018 & 188731,00 & 623,00 & 111664,00 & 76444,00 & 88822,00 & 4441,10 & 72002,90 & 17,21 \\
\hline & 2017 & 188018,00 & 596,00 & 118138,00 & 69284,00 & 111636,00 & 5581,80 & 63702,20 & 12,41 \\
\hline & 2016 & 213209,00 & 545,00 & 153429,00 & 59235,00 & 142691,00 & 7134,55 & 52100,45 & 8,30 \\
\hline & 2015 & 217344,00 & 501,00 & 161296,00 & 55547,00 & 160643,00 & 8032,15 & 47514,85 & 6,92 \\
\hline \multirow[t]{9}{*}{ КД } & 2018 & 230924,00 & 30,00 & 190828,00 & 40066,00 & 186388,00 & 9319,40 & 30746,60 & 4,30 \\
\hline & 2017 & 211568,00 & 30,00 & 168672,00 & 42866,00 & 164293,00 & 8214,65 & 34651,35 & 5,22 \\
\hline & 2016 & 179293,00 & 4,00 & 138042,00 & 41247,00 & 135552,00 & 6777,60 & 34469,40 & 6,09 \\
\hline & 2015 & 150648,00 & 7,00 & 108913,00 & 41728,00 & 105495,00 & 5274,75 & 36453,25 & 7,91 \\
\hline & 2014 & 136733,00 & 118,00 & 84665,00 & 51950,00 & 82806,00 & 4140,30 & 47809,70 & 12,55 \\
\hline & 2013 & 110314,00 & 142,00 & 63961,00 & 46211,00 & 61872,00 & 3093,60 & 43117,40 & 14,94 \\
\hline & 2012 & 94706,00 & 250,00 & 49897,00 & 44559,00 & 48952,00 & 2447,60 & 42111,40 & 18,21 \\
\hline & 2011 & 79856,00 & 266,00 & 38023,00 & 41567,00 & 37243,00 & 1862,15 & 39704,85 & 22,32 \\
\hline & 2010 & 66298,00 & 131,00 & 27795,00 & 38372,00 & 26650,00 & 1332,50 & 37039,50 & 28,80 \\
\hline \multirow[t]{8}{*}{ TAC-life } & 2018 & 2580653,00 & 1124,00 & 2346345,00 & 233184,00 & 2246106,00 & 112305,30 & 120878,70 & 2,08 \\
\hline & 2017 & 2414114,00 & 1278,00 & 2163931,00 & 248905,00 & 2069291,00 & 103464,55 & 145440,45 & 2,41 \\
\hline & 2016 & 1450116,00 & 1647,00 & 1499817,00 & 51348,00 & 1455938,00 & 72796,90 & 124144,90 & $-0,71$ \\
\hline & 2015 & 1415242,00 & 2256,00 & 1284317,00 & 128669,00 & 959435,00 & 47971,75 & 80697,25 & 2,68 \\
\hline & 2014 & 1044738,00 & 2218,00 & 942467,00 & 100053,00 & 731753,00 & 36587,65 & 63465,35 & 2,73 \\
\hline & 2013 & 764985,00 & 2158,00 & 648632,00 & 114195,00 & 618003,00 & 30900,15 & 83294,85 & 3,70 \\
\hline & 2012 & 660265,00 & 1686,00 & 551801,00 & 106778,00 & 523926,00 & 26196,30 & 80581,70 & 4,08 \\
\hline & 2011 & 534462,00 & 1439,00 & 453118,00 & 79905,00 & 366725,00 & 18336,25 & 61568,75 & 4,36 \\
\hline
\end{tabular}

Складено та розраховано за даними [16,17,18,19,20,21].

Висновок.

Solvency II - це нова система нагляду, яка ставить вимоги до необхідного економічного капіталу, управління ризиками та стандартів звітності страхових організацій. Директива Solvency II зосереджується на підході до управління ризиками щодо необхідних стандартів капіталу. ІЇ головна мета полягає в забезпеченні того, щоб страхові компанії мали достатній економічний капітал для захисту страхувальників, оскільки він має на меті зменшити ризик того, що страховик не зможе виконати свої фінансові зобов'язання. В свою чергу, головними показниками, які вказують на високий запас платоспроможності можна назвати статутний капітал, страхові резерви, власний капітал. Аналізуючи річні звіти провідних компаній зі страхування життя ми прийшли до висновку, що всі вони мають рівень платоспроможності, який відповідає нормам українського законодавства та готові до введення вимог Директиви Solvency II. Це надасть страхувальникам більшу довіру до страхових організацій та їх послуг. 3 іншого боку, для збільшення зацікавленості в страхових продуктах важливим етапом у впровадженні Solvency II є достовірність правдивої та доступної інформації щодо можливих змін у кількості представлених на ринку країни компаній і мета буде досягнута.

\section{Список літератури:}

1. Юхименко В.М. Розвиток системи платоспроможності страхових організацій в країнах Європейського союзу/В.М.Юхименко/Вісник Одеського національного університету. Серія : Економіка. - 2015. - Т.20, ВИП.2(2). - С.169-172

2. Юхименко B.M. Solvency II в Україні: проблеми впровадження вимог до платоспроможності страхових організацій - [Електронний ресурс] - Режим доступу: http://www.ej.kherson.ua/journal/economic_12/155.pdf

3. Юхименко B.М. Страховий ринок України в контекст впровадження вимог Solvency II Науковий вісник Ужгородського національного університету. [Електронний ресурс]/Серія : Міжнародні економічні відносини та світове господарство. 02017. - Вип.12(2). - с. 190-193. - Режим доступу: http://nbuv.gov.ua/UJRN/Nvuumevcg_2017_12\%282\%29 43

4. Богомаз Н. Проблеми та перспективи розвитку єдиного страхового ринку країн ЄС / Н. Богомаз // Вісник Київського національного університету імені Тараса Шевченка. [Електронний ресурс]// Економіка. - 2008. - Вип. 106. - С. 13-18. - Режим доступу: http://nbuv.gov.ua/UJRN/VKNU_Ekon_2008_106_6

5. Внукова Н. М. Адаптація вимог Solvency II до умов функціонування страхового ринку України / Н. М. Внукова, С. А. Ачкасова, І. В. Скорик // Фінанси України. - 2013. - № 9. - С. 76-82. 
6. Шлапак Н. С., Кривич Т. Е. Проблеми розвитку страхового бізнесу в сучасних умовах [Електронний ресурс] / Н.С.Шлапак, Т.Е.Кривич. - Режим доступу: http:///ir.pstu.edu/bitstream/handle/123456789/15985/51.pdf?sequence=1

7. Баранова О.В. Вимоги щодо платоспроможності страховиків в країнах ЄС організацій [Електронний ресурс] / О.В.Баранова. - Режим доступу: http://ir.kneu.edu.ua/handle/2010/22897

8. Про страхування: Закон України від 07.03.1996 № 85/96 ВР зі змінами і доповненнями [Електронний ресурс]/ Верховна Рада України. - Режим доступу: http://zakon4.rada.gov.ua/laws/show/85/96- \%D0\%B2\%D1\%80.
9. Solvency
[Electronic
recourse]
Accessed
mode:

https://www.bafin.de/EN/Aufsicht/VersichererPensionsfonds/Aufsichtsregime/Solvencyl/solvency__node_en.html

10. Solvency I vs. Solvency II - [Electronic recourse] - Accessed mode: https://piu.org.pl/public/upload/ibrowser/solvency/o solvency.pdf

11. Позднякова Л.О. Впровадження у вітчизняну практику європейських стандартів контролю й регулювання страхової системи [Електронний ресурс] / Л.О.Позднякова. - Режим доступу: http://ena.lp.edu.ua/bitstream/ntb/32079/1/152-273-274.pdf

12. Розпорядження «Про затвердження Положення про обов'язкові критерії і нормативи достатності капіталу та платоспроможності, ліквідності, прибутковості, якості активів та ризиковості операцій страховика» - [Електронний ресурс] - Режим доступу: http://search.ligazakon.ua/l_doc2.nsf/link1/RE32234.html

13. Статистика страхового ринку України [Електронний ресурс] - Режим доступу: https://forinsurer.com/stat

14. Директива 2009/138/€С Європейського парламенту та ради - [Електронний ресурс] - Режим доступу: http://fspu.com.ua/zakonodavstvo normatyvni akty zarubizhnyh krain

15. Шірінян Л. В. Фінансовий аудит страховика як метод контролю і регулювання діяльності страхової компанії [Електронний ресурс] / Л. В. Шірінян // Формування ринкових відносин в Україні. - 2012. - № 7. - С. 114-119. - Режим доступу: http://nbuv.gov.ua/UJRN/frvu_2012_7_27

16. Фінансова звітність ПрАТ «Метлайф» системи - [Електронний ресурс] - Режим доступу: https://www.metlife.ua

17. Фінансова звітність ПрАТ «СК УНІКА Життя» - [Електронний ресурс] - Режим доступу: https://uniqa.ua/ua/about us/initial_datal

18. Фінансова звітність ПрАТ «СК «КД Життя» - [Електронний ресурс] - Режим доступу: https://www.kdlife.com.ua/ua/about/finreport

19. Фінансова звітність ПрАТ «УСК «Княжа Вієнна Іншуранс Груп» - [Електронний ресурс] - Режим доступу: https://www.kniazha-life.com.ua/finansovi-pokazniki

20. Фінансова звітність ПрАТ «УАСК АСКА-ЖИТТЯ»- [Електронний ресурс] - Режим доступу: http://askalife.com.ua/ukl

21. Фінансова звітність ПрАТ «СК «ТАС» - [Електронний ресурс] - Режим доступу: http://www.taslife.com.ua/pages/open_info

Petrushenko Y.N., Dr, Pofessor, Sumy State University (Sumy, Ukraine)

Boiko O.I., postgraduate, Sumy State University (Sumy, Ukraine)

Solvability as a guarantee for the insurance market development

Life insurance is gradually becoming an integral part of the life of Ukrainian citizens. In order to improve the quality of customer service, efficiency of use of available and attracted resources, identify the problem points and increase the level of competitiveness of insurance organizations, it is necessary to analyze the financial performance of these organizations. The article discusses the main parameters that are key factors in the guarantee system of insurance companies. The main indicators of leading insurers in terms of solvency are analyzed, the solvency margin ratios are calculated and the level of sustainability of these companies is evaluated. The study shows that the solvency margin is quite significant, although in the course of financial activity it tends to change, both minor and significant. In general, the analysis data indicate the availability of insured reserves and the openness of companies' data to the introduction of new legislation that meets the requirements of the Solvency II Directive.

Key words: solvability, actual solvability, normative solvency margin, Solvency I, Solvency II

Дата надходження до редакції: 24.11.2018 p.

Вісник Сумського національного аграрного університету

Серія «Економіка і менеджмент», випуск 1 (79), 2019 